\title{
Modulatory action of FSH on LH-induced follicular growth in rats
}

\author{
J. J. Peluso*, S. Luttmer and M. L. Gruenberg \\ Department of Biology, Loyola University of Chicago, Chicago, Illinois 60626, U.S.A.
}

\begin{abstract}
Summary. Three to four ovaries from rats on the day of di-oestrus I were placed in perifusion culture at $10: 30 \mathrm{~h}$ and exposed to (1) no gonadotrophin (in-vitro controls); (2) tonic FSH (200 ng RP-1/ml); (3) tonic LH (30 ng RP-1/ml); (4) tonic FSH + tonic $\mathrm{LH}$; or (5) tonic FSH plus hourly pulses of LH (amplitude $=50 \mathrm{ng} / \mathrm{ml}$ ). The total amount of LH administered was $3060 \mathrm{ng}$ RP-1 regardless of mode of delivery. After culture for $3 \mathrm{~h}$, the ovaries were prepared for histological analysis. Compared to in-vitro controls, tonic LH stimulation increased the number of follicles with $>1.6 \times 10^{5}$ granulosa cells $(P<0.05)$; it was estimated that each follicle in the larger size class increased by $5.5 \pm 2.7 \times 10^{4}$ cells. Tonic FSH or tonic FSH + tonic LH treatment did not promote growth into the $1.6 \times 10^{5}$ cell class. In the presence of tonic FSH, hourly LH pulses induced follicular growth similar to that observed after tonic LH treatment. The data demonstrate that $\mathrm{LH}$ promotes the growth of follicles in vitro. FSH modulates this stimulatory action of $\mathrm{LH}$, allowing it to be expressed when $\mathrm{LH}$ is administered in hourly pulses.
\end{abstract}

\section{Introduction}

Follicular growth is a complex process that is controlled by gonadotrophins and ovarian steroids (Greenwald, 1974). In-vitro techniques have been utilized to assess the precise roles that these regulators play in controlling follicle growth. These studies show that FSH increases the growth of small preantral follicles by stimulating granulosa cell mitosis (Ryle, 1972). LH promotes thecal cell differentiation (Eshkol, Lunenfeld \& Peters, 1969) and thecal androgen production (Carson, Richards \& Kahn, 1981). The androgen can then be converted into oestrogen by granulosa cells of the developing follicles (Dorrington, 1977). Androgens and oestrogens stimulate follicular growth (Kent, 1973), accounting in part for the growth-promoting actions of LH.

By integrating the data of in-vitro studies with the results of in-vivo tests, an understanding of the complex hormonal interactions necessary to induce follicular development during the oestrous cycle can be gained. It appears that a surge of FSH, which occurs on the morning of oestrus, recruits a cohort of follicles to grow (Hirshfield \& Midgley, 1978; Hoak \& Schwartz, 1980). After recruitment, low levels of LH appear to be required to continue this growth during dioestrus I and II (Bogovich, Richards \& Reichert, 1981). During this period of follicular growth, LH is secreted in discrete hourly pulses of fixed amplitude and duration (Gallo, 1981). In-vitro exposure to LH pulses which mimic those of the dioestrous rat induce follicular growth within the dioestrous I ovary (Peluso, Gruenberg \& Steger, 1984). The purpose of this study was to assess the complex interaction between FSH and LH in their control of follicular growth.

* Present address: Division of Research, Endotronics, Inc., 8500 Evergreen Boulevard, Coon Rapids, MN 55433 , 


\section{Materials and Methods}

The details regarding the preparation of the culture media, and the culture system with the associated mathematical considerations have been published (Gruenberg \& Walker, 1983; Peluso, Downey \& Gruenberg, 1984).

Briefly, bovine luteinizing hormone (NIAMDD-bLH-10) and bovine follicle-stimulating hormone (NIAMDD-bFSH-1) were dissolved in Medium 199 which was supplemented with $2 \cdot 2 \mathrm{~g}$ $\mathrm{NaHCO}_{3} / 1,2 \mathrm{~g} \mathrm{BSA} / 1,50 \mathrm{mg}$ streptomycin sulphate/1, $62.9 \mathrm{mg}$ penicillin $\mathrm{G} / 1$ and $2.38 \mathrm{~g}$ Hepes buffer/l (pH 7.4). LH and FSH concentrations of the solutions were expressed in RP-1 units.

Experimental protocol. Ten female Wistar rats (5-6 months old) were housed under controlled conditions of humidity $(50 \%)$, temperature $\left(24^{\circ} \mathrm{C}\right)$ and photoperiod $(12 \mathrm{~h}$ light $/ 24 \mathrm{~h})$. The animals were fed Purina Lab Chow and water ad libitum. Oestrous cycles were monitored by vaginal smears taken daily between $08: 00$ and 10:00 h. Animals with at least 3 consecutive 4- or 5-day oestrous cycles were used. As assessed by vaginal smear cytology, a rat was considered to be dioestrus I if its vaginal smear was leukocytic and preceded by a predominantly cornified vaginal smear. All rats were autopsied between $10: 00$ and $10: 15 \mathrm{~h}$ on the day of dioestrus I, when follicular distributions (Hirshfield \& Midgley, 1978; Peluso \& Downey, 1982) and hormonal patterns (Butcher, Collins \& Fugo, 1974) are similar in rats with 4- or 5-day cycles. The ovaries were removed, placed in Medium 199 which was supplemented with $400 \mathrm{i} . \mathrm{u}$. heparin sulphate/1 and $200 \mathrm{i}$.u. insulin/l, trimmed of fat and incubated at room temperature for 2-4 min. At 10:30 h each ovary was placed in a separate culture chamber to which $10 \mathrm{ml}$ heparin-free Medium 199 were added. The ovaries were then exposed to the following treatments: (1) no gonadotrophins (in-vitro control); (2) tonic FSH (200 ng FSH-RP-1/ml); (3) tonic LH (30 ng LH-RP-1/ml); (4) tonic FSH + tonic LH; or (5) tonic FSH and pulsatile LH (see Text-fig. 1 from Peluso et al., 1984). Regardless of LH treatment, the total amount of LH to which each ovary was exposed was $3060 \mathrm{ng}$ over the 3-h culture period.

Analysis of follicular development. After culture, the ovaries were fixed in Bouin's solution, dehydrated, embedded in paraffin wax, sectioned at $10 \mu \mathrm{m}$ and stained with haematoxylin and eosin. Four ovaries were examined for each treatment group except Group 2 (tonic FSH) for which 3 ovaries were examined. Histological examinations were made on follicles $\geq 160 \mu \mathrm{m}$ in diameter. All measurements were made on the largest diameter of each follicle. Largest diameters were determined by measuring the section of a follicle that contained the oocyte with a visible nucleus and/or nucleolus. A Zeiss Videoplan Image Analyzer was used to determine the total number of granulosa cells for each follicle. The largest perimeter was estimated by tracing the basement membrane thereby inscribing the granulosa cell layers. The perimeters of the antral cavity and the ovum were also calculated. By using these perimeter measurements, the volume of each follicular component was mathematically determined using the Zeiss Videoplan software. The volume of the antral cavity and ovum was subtracted from the volume of the entire follicle to determine the volume of the granulosa cell layer. To calculate the total number of granulosa cells in a follicle, the volume of the granulosa cell layer was divided by the average volume of a granulosa cell. The average granulosa cell volume, used to calculate the total number of cells per follicle, was $100 \mu \mathrm{m}^{3}$ (determined by measuring the volume of 20 granulosa cells from 5 follicles of each treatment group). The average cell density of the granulosa cells was $9 \cdot 3$ cells $/ 635 \mu \mathrm{m}^{2}$. Neither the cell volume nor the granulosa cell density was affected by any of the in-vitro treatments.

To assess the net increase in the total number of cells per follicle in response to various treatments which induced follicular growth, the total number of cells from the largest follicle in the in-vitro controls was subtracted from the total number of cells in the largest follicle of each treatment group. Pairing was continued until all the follicles with $>160 \times 10^{3}$ cells were accounted for. The data were expressed as the net increase and as the $\%$ increase in the total number of cells per follicle.

Statistical comparisons between and within the different hormone treatment groups were 
evaluated using analysis of variance followed by the Newman-Keul procedure. Values were considered signficantly different if $P<0.05$.

\section{Results}

Although the total number of follicles per ovary remained the same regardless of treatments, some gonadotrophin treatments induced the growth of follicles into the largest class-size. Compared to the in-vitro controls, the number of follicles with $>160 \times 10^{3}$ granulosa cells increased after a 3-h exposure to tonic LH $(P<0.05)$ (Table 1). To account for the growth of follicles into this size-class, it was calculated that each follicle increased by an average of $5.5 \pm 2.7 \times 10^{4}$ granulosa cells $(35 \%)$. Exposure to tonic FSH did not stimulate follicular growth. Simultaneous exposure to tonic levels of FSH and LH inhibited the growth-promoting actions of tonic LH. However, when ovaries were cultured with hourly pulses of LH in the presence of tonic FSH, the number of follicles in the $160 \times$ $10^{3}$ cell size class increased compared to in-vitro controls $(P<0.05)$ (Table 1$)$. Both the number of large follicles as well as the estimated increase in the number of granulosa cells per follicles $(5 \cdot 8 \pm$ $0.9 \times 10^{4}$ granulosa cell/follicles; $39 \%$ ) were similar to that induced by tonic $\mathrm{LH}$ alone.

Histological examination revealed that the interstitium and connective tissue was well maintained throughout the culture period regardless of treatment. Non-atretic and atretic follicles of various sizes were observed; the percentage of atretic follicles was not affected by any of the treatments.

Table 1. The effect of various gonadotrophin treatments on follicular distributions within dioestrous rat ovaries after culture for $3 \mathrm{~h}$

\begin{tabular}{|c|c|c|c|c|c|}
\hline \multirow[b]{2}{*}{$\begin{array}{l}\text { Follicle size } \\
\text { class } †\end{array}$} & \multicolumn{5}{|c|}{ Treatments } \\
\hline & $\begin{array}{l}\text { No } \\
\text { gonadotrophin }\end{array}$ & Tonic LH & Tonic FSH & $\begin{array}{c}\text { Tonic FSH }+ \\
\text { tonic } \mathrm{LH}\end{array}$ & $\begin{array}{c}\text { Tonic FSH + } \\
\text { pulsed LH }\end{array}$ \\
\hline$\geq 160$ & $2 \cdot 3 \pm 1 \cdot 2$ & $6.75 \pm 1.1^{*}$ & $3 \cdot 3+0 \cdot 8$ & $4 \cdot 0+0 \cdot 5$ & $8 \cdot 0+1 \cdot 9^{*}$ \\
\hline $80-159$ & $15 \cdot 3 \pm 2 \cdot 2$ & $14 \cdot 0 \pm 2 \cdot 7$ & $13 \cdot 3 \pm 2 \cdot 3$ & $13 \cdot 5 \pm 2 \cdot 6$ & $14.7 \pm 1.5$ \\
\hline $40-79$ & $11.8 \pm 1.2$ & $16 \cdot 5 \pm 1 \cdot 2$ & $13 \cdot 0 \pm 2.8$ & $11 \cdot 8 \pm 1 \cdot 3$ & $14 \cdot 3 \pm 1 \cdot 1$ \\
\hline $20-39$ & $9 \cdot 0 \pm 1.7$ & $12 \cdot 0 \pm 2 \cdot 4$ & $11.7 \pm 1.6$ & $12.5 \pm 1.8$ & $11 \cdot 3 \pm 3 \cdot 1$ \\
\hline $10-19$ & $7 \cdot 0 \pm 0.8$ & $8 \cdot 0 \pm 1 \cdot 2$ & $14 \cdot 3 \pm 2 \cdot 7$ & $11 \cdot 5 \pm 2 \cdot 9$ & $9 \cdot 0 \pm 1 \cdot 2$ \\
\hline $\begin{array}{l}\text { Total no. of } \\
\text { follicles per ovary }\end{array}$ & $45 \cdot 3 \pm 5 \cdot 3$ & $57 \cdot 3 \pm 4 \cdot 4$ & $55 \cdot 6 \pm 2 \cdot 3$ & $53 \cdot 3 \pm 7 \cdot 1$ & $57 \cdot 3 \pm 4 \cdot 8$ \\
\hline
\end{tabular}

Values are mean \pm s.e.m.

* Significantly different from other values in the same size class $(P<0.05)$ but not from each other $(P>0.05)$.

$\dagger$ No. of cells/follicle $\times 1000$.

\section{Discussion}

The present results demonstrate that LH plays a dominant role in stimulating the growth of follicles within cultured ovaries from rats on the day of dioestrus I. In hamsters that are hypophysectomized at oestrus, tonic LH levels, maintained by constant infusion, stimulate follicular growth and result in the development of preovulatory follicles after 3 days of treatment (Shaban \& Terranova, 1983). Low levels of LH can also stimulate follicles to grow in intact progesterone-implanted prepubertal rats (Richards, Jonassen \& Kersey, 1980; Richards \& Bogovich, 1982). During dioestrus I (Butcher et al., 1974) and late pregnancy (Richards \& Kersey, 1979; Bogovich et al., 1981), LH values are low and progesterone concentrations are elevated. In both of these physiological states, LH potentiates 
the growth of follicles with progesterone facilitating the actions of LH (Richards \& Bogovich, 1982). The present in-vitro study therefore confirms the growth-promoting property of LH.

Follicular growth cannot be supported by FSH alone and requires additional LH stimulation (Lostroh \& Johnson, 1966; present study). Further, in the presence of FSH, the ovary responds differently to LH depending on whether LH is administered in a tonic or pulsatile manner even though the total amount of LH exposure is the same. FSH overrides the growth-promoting actions of LH if LH is administered in a tonic manner. However, hourly LH pulses can overcome this FSHinduced inhibition of follicular growth. This observation suggests that FSH plays an important role in modulating the stimulatory actions of LH on follicle growth within the ovary of dioestrous rats.

The present results also confirm that follicles can be stimulated to grow in vitro. It is estimated that the number of granulosa cells per follicle increases by $11.7 \% / \mathrm{h}$ after tonic $\mathrm{LH}$ exposure and $13.0 \% / \mathrm{h}$ after hourly $\mathrm{LH}$ pulses in the presence of FSH. This percentage increase in granulosa cells represents the cell growth fraction $\left(\mathrm{K}_{\mathrm{G}}\right)$. Assuming that the ovarian follicles grow exponentially (Pederson, 1970), the time required for the follicle to double $\left(t_{\mathrm{D}}\right)$ can be calculated using the following equation: $t_{\mathrm{D}}=\ln 2 / \mathrm{K}_{\mathrm{G}}$ (Aherne, Camplejohn \& Wright, 1977). Since the growth fraction was statistically the same for follicles exposed to tonic $\mathrm{LH}$ or FSH $+\mathrm{LH}$ pulses of $50 \mathrm{ng} \mathrm{LH} / \mathrm{ml}$, the $t_{\mathrm{D}}$ for follicles is estimated to range from 5.3 to $5.9 \mathrm{~h}$. This estimated $t_{\mathrm{D}}$ is shorter than the average $t_{\mathrm{D}}$ of follicles of the mouse (i.e. $17 \mathrm{~h}$ ) (Pederson, 1970). The reasons for this disparity in estimated follicle doubling times are unknown.

In conclusion, this study demonstrates that $\mathrm{LH}$ promotes the growth of ovarian follicles in vitro. FSH modulates this stimulatory action of LH allowing it to be expressed only when LH is administered in hourly pulses of specific amplitude.

We thank NIAMDD for the gifts of the FSH and LH used in these experiments.

\section{References}

Aherne, W.A., Camplejohn, R.S. \& Wright, N.A. (1977) An Introduction to Cell Population Kinetics. University Park Press, Baltimore.

Bogovich, K., Richards, J.S. \& Reichert, L.E., Jr (1981) Obligatory role of $\mathrm{LH}$ in the initiation of preovulatory follicular growth in the pregnant rat: specific effects of human chorionic gonadotropin and folliclestimulating hormone on $\mathrm{LH}$ receptors and steroidogenesis in theca, granulosa, and luteal cells. Endocrinology 109, 860-867.

Butcher, R.L., Collins, W.E. \& Fugo, N.W. (1974) Plasma concentration of $\mathrm{LH}, \mathrm{FSH}$, prolactin, progesterone and estradiol-17 $\beta$ throughout the 4-day estrous cycle of the rat. Endocrinology 94, 1704-1708.

Carson, R.S., Richards, J.S. \& Kahn, L.E. (1981) Functional and morphological differentiation of theca and granulosa cells during pregnancy in the rat: dependence on increased basal luteinizing hormone activity. Endocrinology 109, 1433-1441.

Dorrington, J.H. (1977) Steroidogenesis in vitro. In The Ovary, 2nd edn, Vol. 3, pp. 359-399. Eds S. Zuckerman \& B. J. Weir. Academic Press, New York.

Eshkol, A., Lunenfeld, B. \& Peters, H. (1969) Ovarian development in infant mice. Dependence on gonadotropic hormones. In Gonadotropins and Ovarian Development, pp. 249-258. Eds W. R. Butt, T. Pedersen \& H. Peters. Williams and Wilkins, Baltimore.
Gallo, R.V. (1981) Pulsatile LH release during periods of low level LH secretion in the rat estrous cycle. Biol. Reprod. 24, 771-777.

Greenwald, G.S. (1974) Role of FSH and LH in follicular development and ovulation. In Handbook of Physiology, Vol. II, pp. 293-323. American Physiological Society, Washington, D.C.

Gruenberg, M.L. \& Walker, R.D. (1983) A new technique for controlled delivery of biochemical regulatory agents to isolated tissue in culture. Biotechniques June-July issue, pp. 84-89.

Hirshfield, A.N. \& Midgley, A.R., Jr (1978) The role of FSH in the selection of large ovarian follicles in the rat. Biol. Reprod. 19 606-611.

Hoak, D.C. \& Schwartz, N.B. (1980) Blockade of recruitment of ovarian follicles by suppression of the secondary surge of follicle-stimulating hormone with porcine follicular fluid. Proc. natn. Acad. Sci. U.S.A. 77, 4953-4956.

Kent, J. (1973) Some effects of steroids on the immature mouse ovary in vitro. J. Reprod. Fert. 34, 297-303.

Lostroh, A.J. \& Johnson, R.E. (1966) Amounts of interstitial cell-stimulating hormone and folliclestimulating hormone required for follicular development, uterine growth, and ovulation in the hypophysectomized rat. Endocrinology 79, 991-996.

Pederson, T. (1970) Follicle kinetics in the ovary of the cyclic mouse. Acta endocr., Copenh. 64, 304-323.

Peluso, J.J. \& Downey, C. (1982) Pattern of follicular 
development during the estrous cycle of aged rats. Cell Tiss. Res. 225, 229-233.

Peluso, J.J., Gruenberg, M.L. \& Steger, R.W. (1984) Regulation of ovarian follicular growth and steroidogenesis by low amplitude LH pulses. Am. J. Physiol. 246, R184-R 189.

Peluso, J.J., Downey, C. \& Gruenberg, M.L. (1984) Role of LH pulse amplitude in controlling ovarian oestradiol-17 7 secretion in vitro. J. Reprod. Fert. 71, $107-112$.

Richards, J.S. \& Bogovich, K. (1982) Effects of human chorionic gonadotropin and progesterone on follicular development in the immature rat. Endocrinology 111, 1429-1438.

Richards, J.S. \& Kersey, K.A. (1979) Changes in theca and granulosa cell function in antral follicles developing during pregnancy in the rat: gonadotrophin receptors, cyclic AMP and estradiol-17ß. Biol. Reprod. 21, 1185-1201.

Richards, J.S., Jonassen, J.A. \& Kersey, K.A. (1980) Evidence that changes in tonic luteinizing hormone secretion determine the growth of preovulatory follicles in the rat. Endocrinology 107, 641-648.

Ryle, M. (1972) The growth in vitro of mouse ovarian follicles of different sizes in response to purified gondotrophins. J. Reprod. Fert. 30, 395-405.

Shaban, M.S. \& Terranova, P.F. (1983) Regulation of development of preovulatory follicles by FSH and LH in hypophysectomized hamsters. Endocrinology 112, Suppl., p. 300, Abstr. 879.

Received 24 January 1984 